\title{
LAMELLAR INCLUSIONS IN THE CYTOPLASM OF CILIATED CELLS
}

\author{
I. TĚŠIK \\ Department of Histology and Embryology, 1st Medical Faculty \\ Charles University, 12800 Prague
}

\begin{abstract}
Těšík I.: Lamellar Inclusions in the Cytoplasm of Ciliated Cells. Acta vet. Brno, 63, 1994: 95-97.

Numerous osmiophilic inclusions, with matrix arranged into concentric lamellae, were found in a zone between the nucleus and the subciliary layer of mitochondria in the apical cytoplasm of ciliated cells of the tracheal epithelium in the wild cat (Felis silvestris) and the tortoise Testudo hermanni.

Their presence could be related to the existence of the granular endoplasmic reticulum and the Golgi complex in the cells. Their development by local coiling and condensation of the cytoplasm or by metamorphosis of mitochondria is also discussed.
\end{abstract}

\section{Ciliated cell, lamellar inclusion, upper respiratory tract}

The ultrastructural morphology of the ciliated cell, as revealed by electron microscopy, was studied about 25 years ago by a number of authors (Rhodin and Dalham n 1956; Nils on 1958; Dalhamn 1961; Stegner 1961; Fredricsson and Björkman 1962; Gompel 1962; Larsen 1962; Nakai and Nagae 1970 and others). Their descriptions have shown general characteristics common to ciliated cells found in most animal species.

Specific differences in the morphology of ciliated cells were investigated in amphibians by Tě́i $\mathbf{k}(1978)$ and in reptiles by Těsík $(1980,1982,1984)$ and Těsík and Nedvěd (1976).

However, with two exceptions, there are no mentions of the presence of any electron-dense myelin structures in the cytoplasm of ciliated cells in the mucosal lining of the upper respiratory passages. Pa velk a et al. (1976) have reported the findings of large electron-dense granules with lamellarly arranged content in the ciliated cells of the domestic cat (Felis domestica) and Těsík (1982) observed similar granules in the same tissue of the tortoise Testudo hermanni.

\section{Materials and Methods}

In our research on the comparative morphology of respiratory epithelium in the large air passages of vertebrates, 47 animal species were investigated ( 4 amphibian, 21 reptile, 7 avian and 15 mammalian species). Out of these, only the wild cat (Felis silvestris) and tortoise (Testudo hermanni) showed the presence of electron-dense granules with contents corresponding to myelin formations.

Samples of trachea, three from each species, were taken from adult animals of both sexes. Tissue was collected from the approximate centre and near the bifurcation of the trachea. Mucosa was fixed together with the supporting cartilage of the tracheal ring, which facilitated oriented embedding and sectioning.

The tissues were fixed $1 \% \mathrm{OsO}_{4}$ in $0.1 \mathrm{M}$ phosphate buffer, $\mathrm{pH} 7.4$, for $3 \mathrm{~h}$ at $0{ }^{\circ} \mathrm{C}$ or with $2.5 \%$ glutaraldehyde in the same buffer for $2 \mathrm{~h}$ with subsequent fixation in $1 \% \mathrm{OsO}_{4}$ at $0{ }^{\circ} \mathrm{C}$ for $1 \mathrm{~h}$. Embedding was performed with Durcupan ACM by the method of Těs ík and Volfo vá (1978). Blocks were cut using glass knives. Ultrathin sections were contrasted (Re y nolds 1963) and examined with a Tesla BS 500 electron microscope.

\section{Results}

The cytoplasm of ciliated cells observed by electron microscopy was generally light and homogenous. Its supranuclear region, however, appeared darker due to the presence of minute, striated projections extending from the basal bodies of cilia and due to a subciliary layer of densely aggregated mitochondria. In addition, numerous distinct dark granules, which formed clusters reaching up to the nucleus, were seen under the mitochondrial layer in the wild cat. Similar structures, though less frequent, were observed in the tortoise.

None of the other species examined showed similar granules in the cytoplasm of ciliated cells.

Electron microscopy demonstrated the presence of the smooth and granular endoplasmic 
reticulum (ER) in the cytoplasm of ciliated cells (Plates III, V and VI, Figs 1, 4 and 8). The Golgi complex, usually well developed (Plates III and VI, Figs 1 and 10), was located at the approximate boundary of the central and apical parts of the cell. The large zone between the Golgi complex and the nucleus contained the electron-dense granules (Fig. 1). Single granules were spherical in shape. Most of them consisted of dark osmiophilic material arranged into fine, concentric lamellae (Plates III, IV and V, Figs 1, 3, 4, 5 and 7). Some granules, however, contained homogenous or finely precipitated matrix which, occasionally, was in the process of condensing into the lamellar structure (Figs 1, 4 and 7). Some other granules showed fusion and liquefaction of lamellae with a gradual transformation into vacuoles (Figs 4 and 5). Only few granules were in direct contact with the nucleus (Plate V, Fig. 6).

In the zone containing the granules, the cytoplasm often showed thickening and coiling (Plate VI, Figs 8 and 9). In the supranuclear region, an infrequent occurrence of atypical mitochondria with modified and slightly concentrically arranged cristae was recorded (Fig. 10).

In the tortoise, as in the wild cat, clusters of spherical, dark osmiophilic granules were observed between the nucleus and mitochondrial zone in the cytoplasm of ciliated cells. Their matrix was either homogenous or condensed to form fine, dense, concentrically arranged lamellae of myelin character (Plate VI, Fig. 11).

\section{Discussion}

In agreement with the findings of Pavel ka et al. (1976) made in the domestic cat, we found the osmiophilic granules with lamellar content in the cytoplasm of ciliated cells in the wild cat and also in the tortoise Testudo hermanni. In addition, we found that, in the wild cat, the ciliated epithelial cells of the tracheal lining contain, apart from the smooth ER, a considerable amount of the membranes of granular ER and a well developed Golgi complex. The granules, which are apparently the products of these organelles, resembled, to a great extent, the structures found in the granular cells described by Těšík $(1980,1984)$ in reptiles and by Těšík $(1978)$ and Platz $(1985,1986)$ in amphibians. Although many of the granules underwent the process of liquescence, the vacuoles arising from them were not observed to spill their content onto the mucosal surface.

The development of these osmiophilic inclusions could also be accounted for by the local rotation of cytoplasm associated with its thickening, which was found in many instances. This process could be analogous to that described by Ant alík ová (1980) during the formation of osmiophilic lamellar inclusions in developing granular pneumocytes.

The electron-dense granules of ciliated cells could also, as a third explanation, be derived from mitochondria. In several instances, the supranuclear region showed the presence of spherical structures resembling, on the one hand, the primary granules at the beginning of the lamellar process and, on the other hand, modified mitochondria with remnants of cristae in the mitochondrial matrix.

Because the content of the granules undergoes liquefaction but does not spill outside the cell, it could also be speculated that the granules serve as lysosomes in which the content is later utilized by the ciliated cell.

\section{Lamelární inkluze v cytoplazmě řasinkových buněk}

V apikální cytoplazmě řasinkových buněk výstelkového epitelu průdušnice jsme u kočky divoké (Felis silvestris) a želvy zelenavé (Testudo hermanni) v oblasti mezi jádrem a subciliární zónou mitochondrií nalezli četné osmiofilní inkluze, jejichž matrix byla uspořádána do podoby koncentricky serazených lamel. 
Jejich vznik je možno spojovat s existencí granulárního endoplazmatického retikula a Golgiho komplexu v buňkách. Je však též možné, že by mohla vznikat lokálním spirálovitým stáčením a kondenzací cytoplazmy, nebo i metamorfózou mitochondrií.

\section{Пластинчатое включение в цитоплазме ресничных клеток}

В верхушечной цитоплазме ресничных клеток эпителия трахеи дикой кошки (Felis silvestris) и черепахи зеленоватой (Testudo hermanni) в области между ядром и субциллиарной зоной митохондрий обнаружили многочисленные осмифильные включения, основа которых приобретала форму концентрически сгруппированных пластинок.

Их возникновение можно связать с существованием гранулярной эндоплазматической сеточки и комплекса Гольджи в клетках.

Однако существует также возможность их возникновения местным спиральным скручиванием и конденсацией цитоплазмы или метаморфозом митохондрий.

\section{References}

ANTALIKOVÁ, L.: Formation of lamellar inclusion bodies in granular pneumocytes during development. Folia morphol. (Prague), 2, 1980: 197-200.

DALHAMN, T.: Studies on the effect on sulphur dioxide on ciliary activity in rabbit trachea in capacity of the nasal cavity. Amer. Rev. Resp. Dis., 83, 1961: 566-567.

FREDRICSSON, B.-BJÖRKMAN, N.: Studies on the ultrastructure of the human oviduct epithelium in different functional states. Z. Zellforsch., 58, 1962: 387-402.

GOMPEL, C.: The ultrastructure of the human endometrial cell studied by electron microscopy. Amer. J. Obstet. Gynec., 84, 1962: 1 000-1 009.

LARSEN, J.: Electron microscopy of the uterine epithelium in the rabbit. J. Cell. Biol., 14, 1962: 49-64.

NAKAI Y.-NAGAE, Y.: Electron microscopical observations on the function of the tracheal epithelium with special references to ciliated cells. Pract. Oto. Rhino. Laryng., 32, 1970: 202-210.

NILSSON, O.: Electron microscopy of the fallopian tube epithelium of rabbit in estrus. Exp. Cell. Res., 14, 1958: 431-454.

PAVELKA, M.-RONGE, H.-STOCKINGER, G.: Vergleichende Untersuchungen am Trachealepithel verschiedener Säuger. Acta Anat., 94, 1976: 262-282.

PLATZ, F.: Strukturelle Schwingungsanpassungen der Plicae vocales in Larynx der Erdkröte (Bufo bufo). 80. Versammlung Anat. Ges. Abstrakts, Praha, 1985: 104-105.

PLATZ, F.: Ultrastrukturella Befunde an den Schallblasen der Grünen Wasserfrosches (Rana esculenta) und Braunen Grasfrosches (Rana temporaria). 81. Versammlung Anat. Ges. abstrakts, Lübeck, 1986: 126.

REYNOLDS, E.: The use of lead citrate at high $\mathrm{pH}$ as an electron opaque stain in electron microscopy. J. Cell. Biol., 17, 1963: 208-212.

RHODIN, J.-DALHAMN, T.: Electron microscopy of the tracheal ciliated mucosa in rat. Z. Zellforsch., 44, 1956: $345-412$.

STEGNER, H.: Das Epithel der Tuba uterina des Neugeborenen. Z. Zellforsch., 55, 1961: 247-262.

TĚŚfK, I.: Ultrastructure of upper respiratory tract epithelium of certain species of amphibians. Proc. XIXth Morphol. Congr. Praha, 1978: 451-456.

TÉŚ́K, I.: Ultrastructure of the ciliated cells of the tracheal epithelium in reptiles. Folia Morphol. (Prague), 2, 1980: 181-183.

TẺ ŚlK, I.: Ultrastructural morphology of the tracheal epithelium of some species of testudinates. Folia Morphol. (Prague), 4, 1982: 412-414.

TĚŚIK, I.: The ultrastructure of the tracheal epithelium in european common lizard (Lacerta agilis L.) and in sand lizard (Lacerta vivipara Jacq.). Anat. Anz. Jena, 155, 1984: 329-340.

TĚŠIK, I.-NEDVĚD, J.: Ultrastructure of the epithelium of trachea and extrapulmonary bronchi in Gekko gecko. Folia Morphol. (Prague), 24, 1976: 35-40.

TĚŠ́K, I.-VOLFOVÁ, B.: An economical way of embedding specimens in the polymerizing resin Durcupan ACM Fluka for electron microscopy. Folia Morphol. (Prague), 1, 1978: 38-41. 


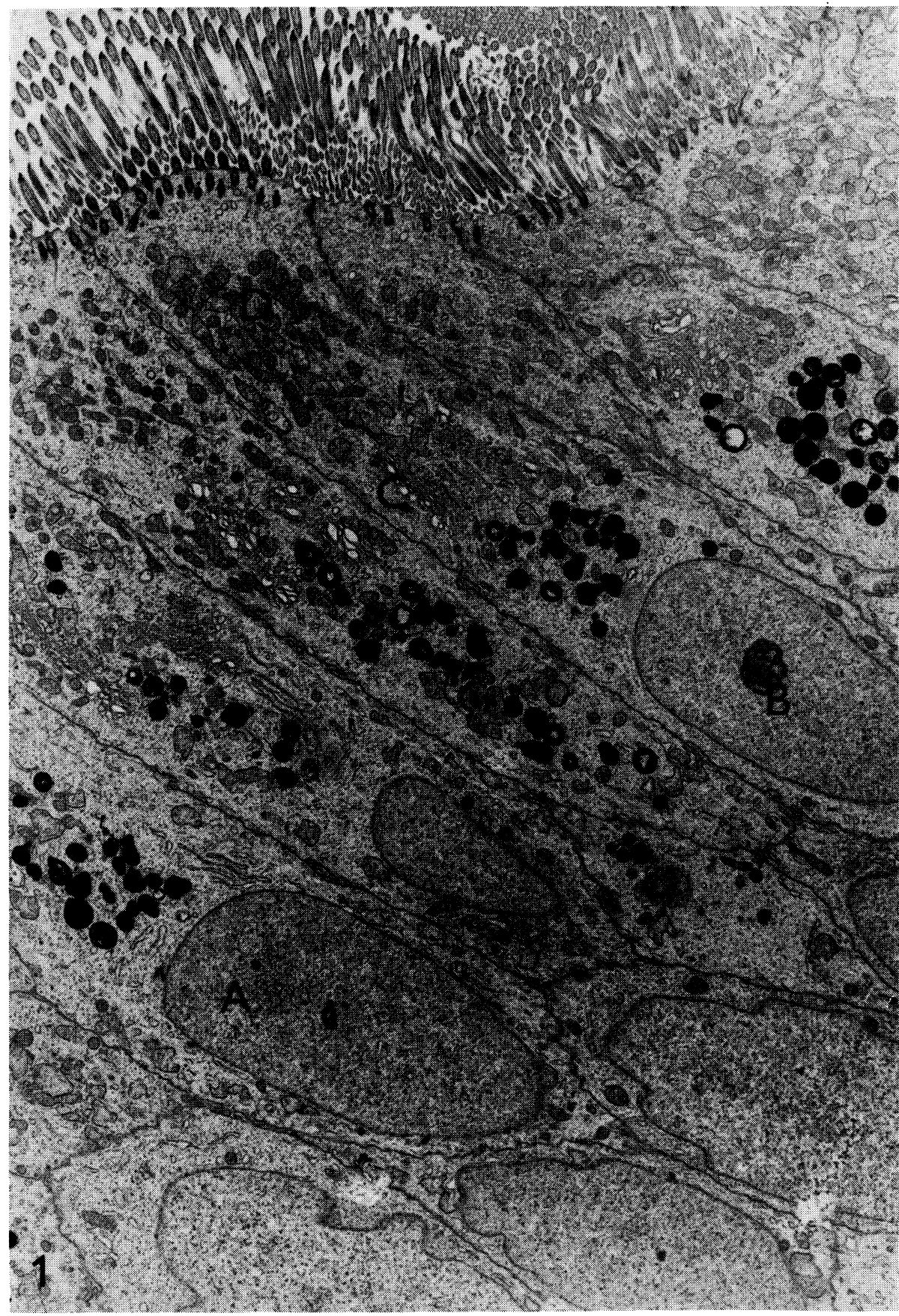

Fig. 1: Felis silvestris. Ciliated cells of the tracheal epithelium are cylindrical in shape. Distinct clusters of osmiophilic inclusions between the nucleus (A) and the nucleolus (B) and Golgi complex (C). Clear zone of subciliary mitochondria (D) in the parts of the cells. $\times 1500$. 
Plate VI.

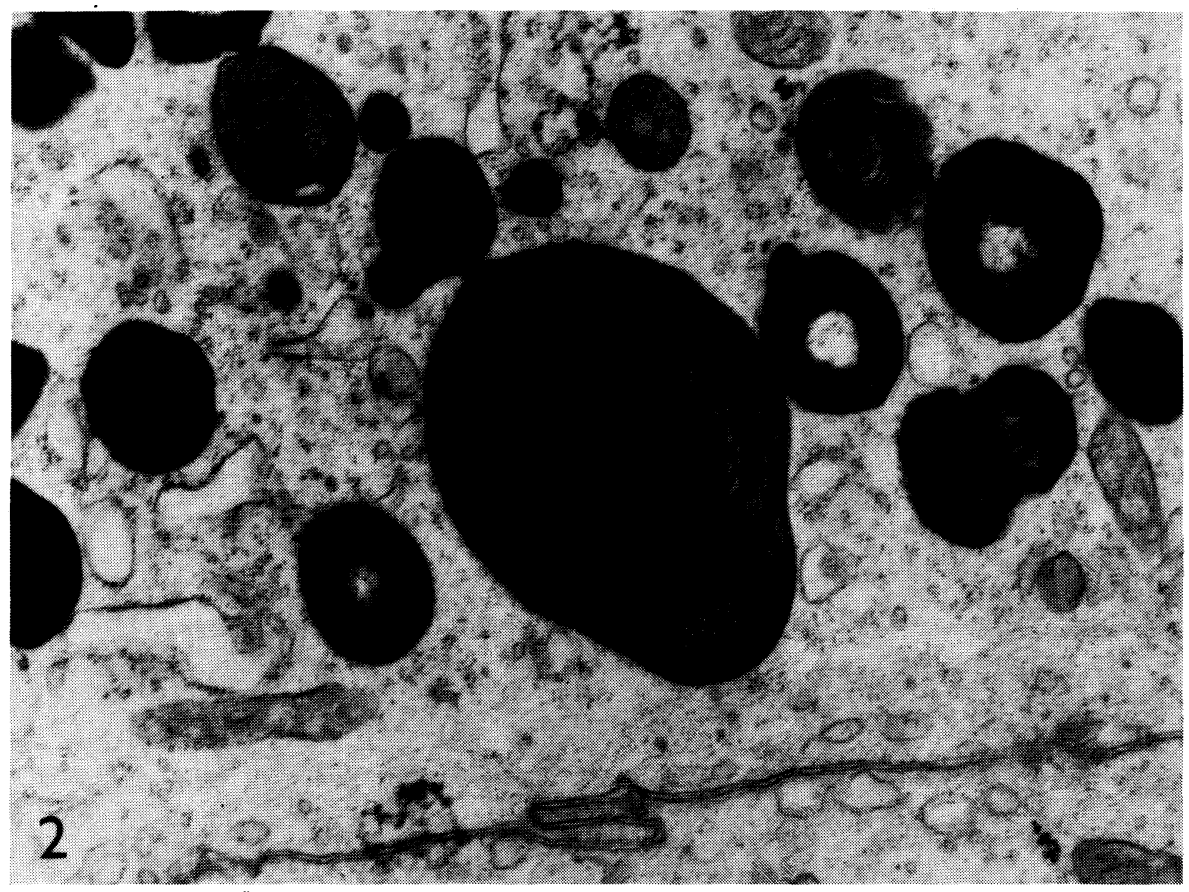

Fig. 2: Felis silvestris. Electron-dense granules with homogenous or finely precipitated matrix in the process of condensing into a lamellar arrangement. $\times 7000$.

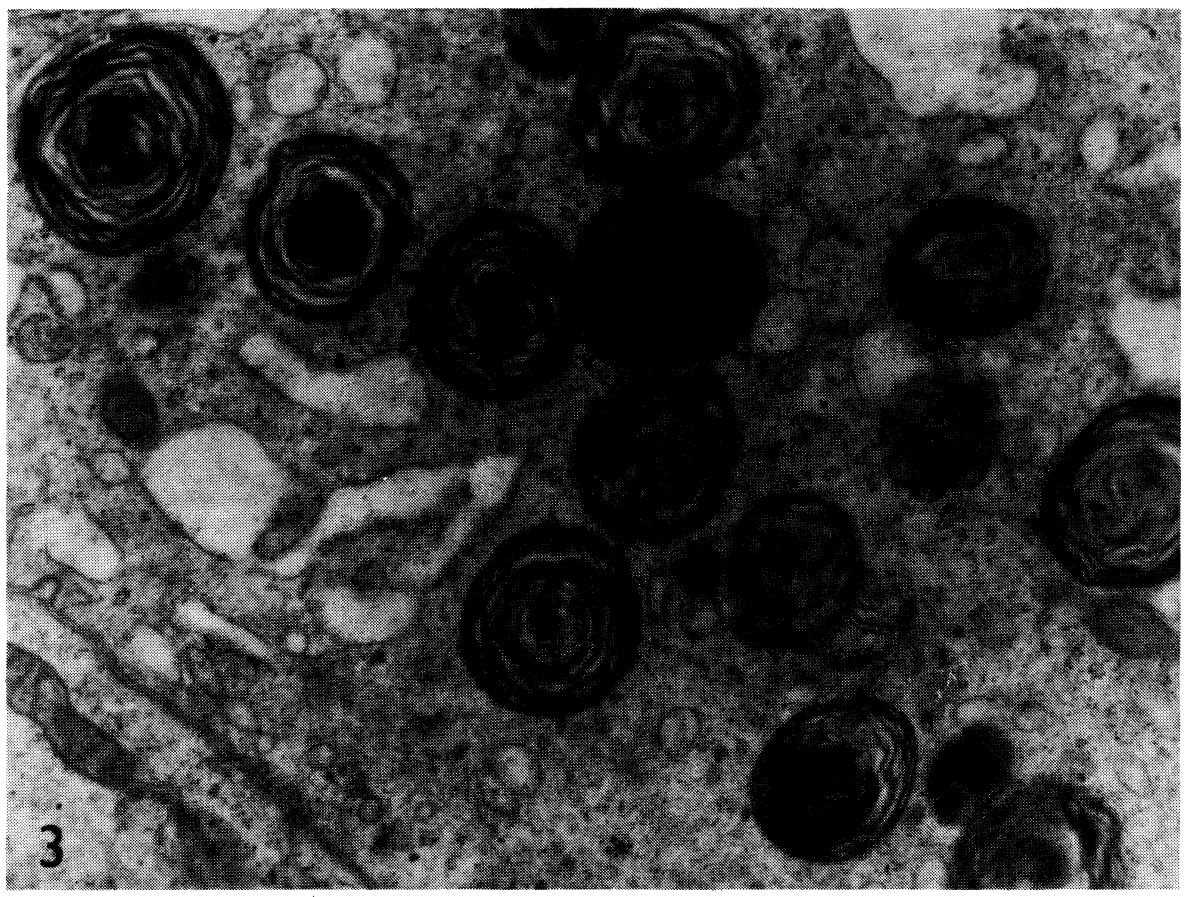

Fig. 3: Felis silvestris. Electron-dense material of the osmiophilic granules is concentrated in fine, concentric lamellae. $\times 1200$. 
Plate VII.
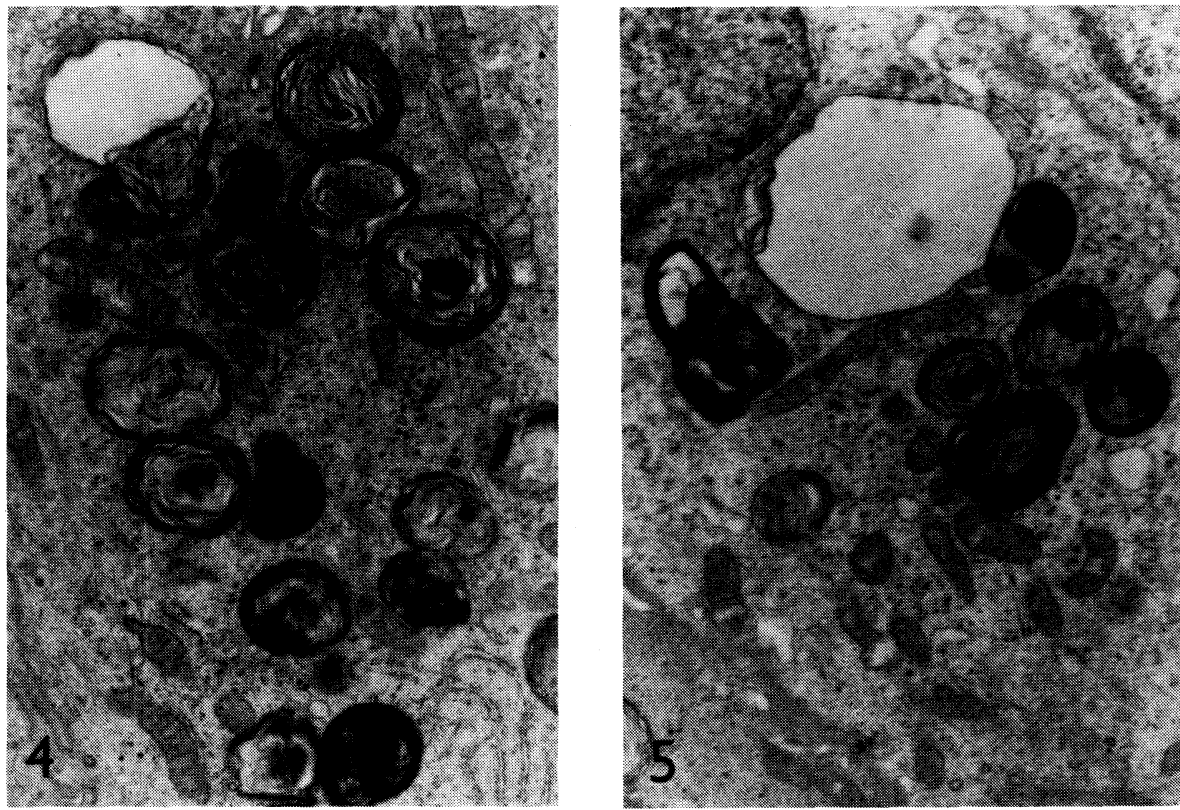

Fig. 4 and 5: Felis silvestris. Some osmiophilic granules in the process of liquescence of lamellae and transformation into vacuoles. $\times 7000$.
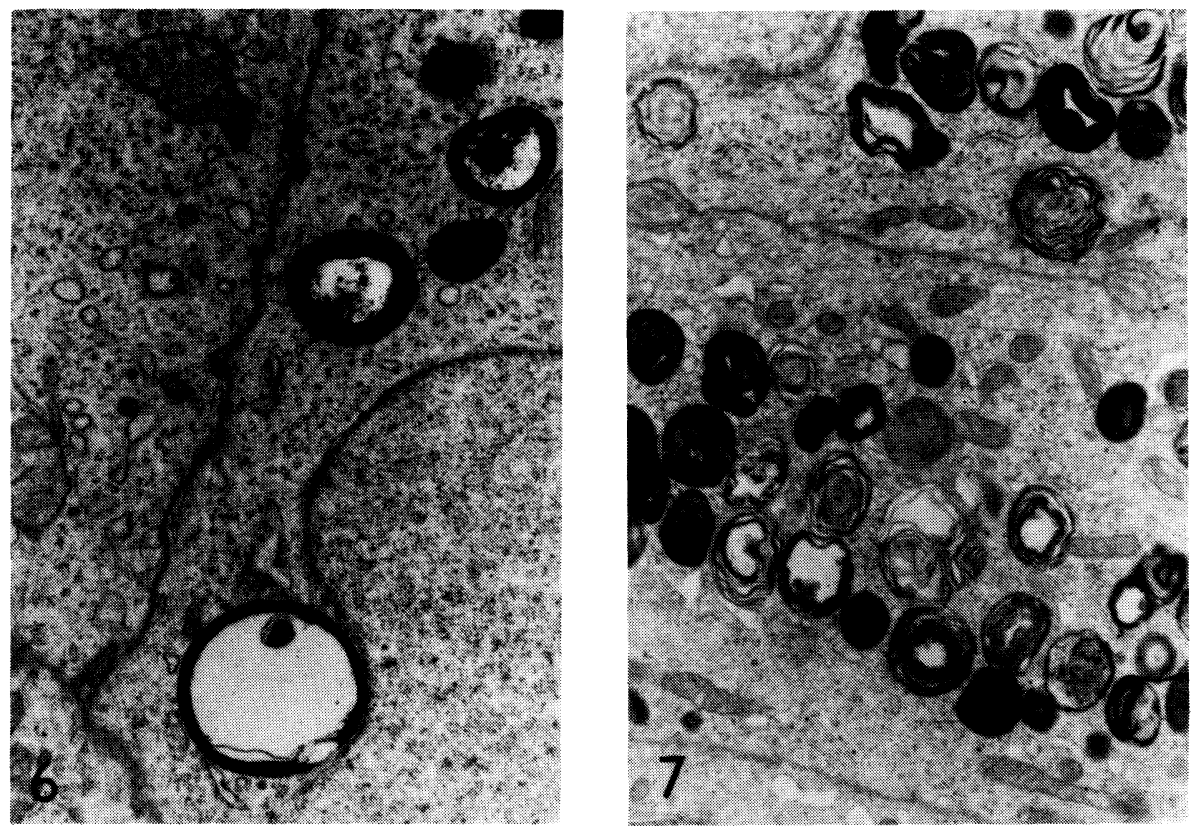

Fig. 6: Felis silvestris. An osmiophilic granule with partially liquescent content, in direct contact with the nuclear envelope. $\times 9000$.

Fig. 7: As in Figs 4 and 5. 
Plate VIII.
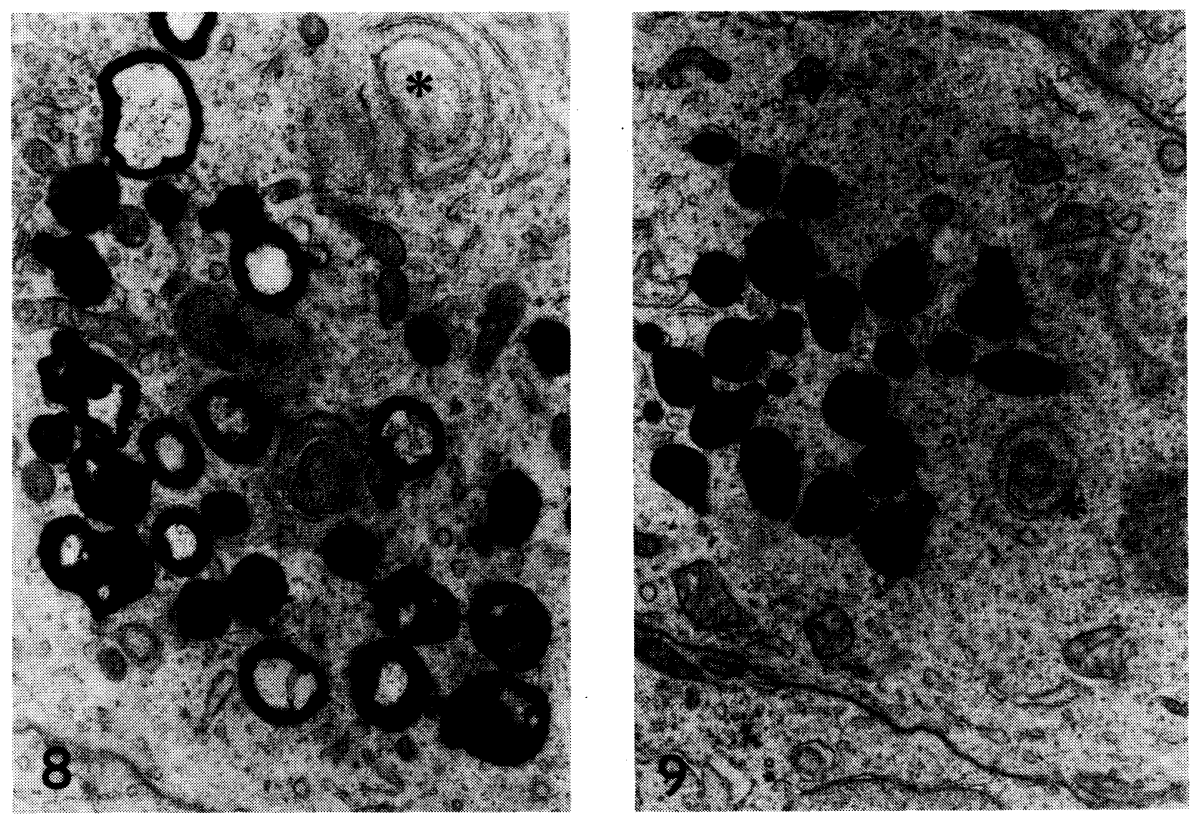

Fig. 8 and 9: Felis silvestris. *Local condensation and coiling of the cytoplasm as a possible basis for the development of the granules. $\times 7000$.
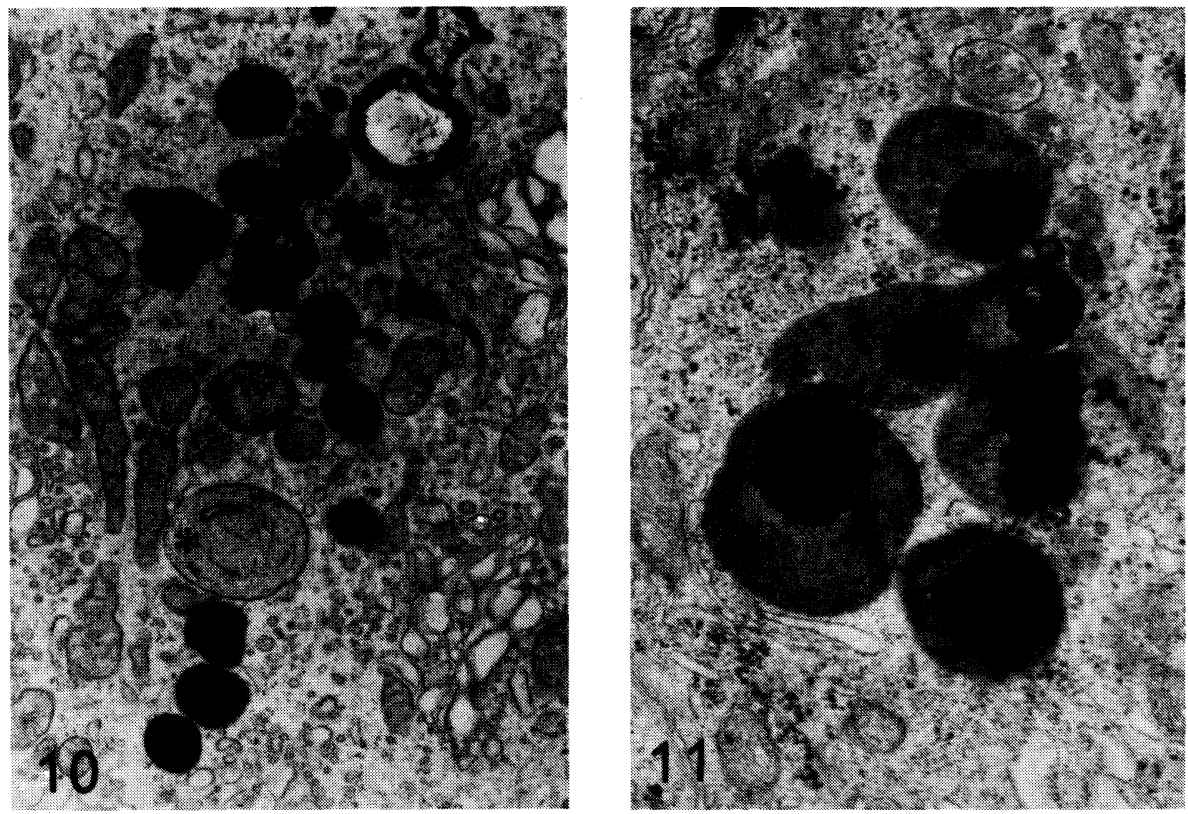

Fig. 10: Felis silvestris. *A potential precursor of the osmiophilic granule resembling a modified mitochondrium. $\times 7000$.

Fig. 11: Testudo hermanni. Osmiophilic granules in the cytoplasm of a ciliated cell. $\times 16000$. 